\title{
Women Participation and Empowerment System under Government Institutions and Constitution from 1971-2020
}

\section{A S M Monowarul Islam}

Principal, UttarBangla University College, Kakina, Lalmonirhat, Bangladesh.

\begin{abstract}
This study focuses on the vital points of women participation and empowerment system under government institution and constitution through exploring previous hypothetical strategic women empowerment model. Women's Empowerment is one of the most challenging steps in our society. They are deprived of political leadership opportunities at all levels of the government. Their equal participation in governance and all other sectors is not only a matter of participation or democracy but also it is natural that women's interest to be taken into account as a strong issue. For the sake of the true development of a society women's participation in every section of life is a must. And most of the countries of the world have understood the fact that by keeping half of the population idle at home, progress is not possible and at the same time women will be deprived of their human rights. As human beings, they have equal rights like men to lead a life with dignity and they have the same potentiality to do something for the betterment of this world. Environment and facilities must be increased so that women can enhance their confidence, develop their skills and personality to play a vital role in the development of society as well as a country. Their rights must be included and preserved by the constitution of a country. In Bangladesh, the constitutional safeguard can be seen as a milestone for ensuring women's equal access and increased participation in political power structure for ensuring their participation, strengthening the government as well as for the sustainable development of Bangladesh. Undoubtedly, the elected reserve seats for women by the constitutions help to promote participation and women's access to the decision-making process. Through their participation is not practically much ensured, reserve seats promote women empowerment. But it is a matter of sorrow that, due to social, political, and cultural barriers, elected women members in government institutions cannot play their effective role. This study seeks to critically evaluate the extent of women's political participation and empowerment under government institutions and constitution from 1971-2020.
\end{abstract}

Keywords: Women Empowerment, democracy, human rights, political and cultural barriers, political participation.

\section{Introduction:}

The disempowerment of women is a stain on human civilization. Women's empowerment is the most important prerequisite of the national development of any country. Women have been empowered in all western countries. They have found their due place of importance in the developed countries which eventually accelerated the development and progress of those countries. Our neighboring country India also has a Women Empowerment Policy. Our government has realized the importance of women's empowerment for national development.

The Government of Bangladesh formulated the first National Women's Development Policy in 1997. The main objective of this policy was to improve the living standards of women of 
different ages in the society who have been subjected to various forms of abuse and neglect for centuries. The policy was formulated in 1997 through extensive consultation and exchange of views with the leaders of the women's movement in the country and those who had long struggled to establish women's rights.

Later, when the government changed, the four-party coalition government changed the policy and formulated a women's development policy. Under the caretaker government, the Women's Development Policy was revised in 2008 but could not be implemented.

In 2008, the Bangladesh Awami League in its election manifesto reiterated its commitment to reinstate the women's development policy formulated by the then Awami League government in 1996. Implementing electoral promises and women's development and women's empowerment to ensure this, the present government under the leadership of Sheikh Hasina has formulated the Women Development Policy 2011.

Here, the goals of the Women's Development Policy, its implementation, as well as the various strategies for its implementation in women's empowerment in Bangladesh are discussed. The paper identifies the challenges that women need to address and suggests some effective steps to overcome them.

\section{Research Objectives:}

The main objective of the research is to explore the challenges and barriers of women empowerment in Bangladesh. Women's participation in different activities is increasing day by day here in Bangladesh for the Women Empowerment Policy taken by the present government. Our government has realized that women can play a vital in national development as they formed half of the total population. Our constitution also preserves the rights of women so that they can participate in different social, political, and development work and they can enjoy equal rights to men. Yet, for some social, political, and cultural barriers, the goal of women's participation cannot be fulfilled. This study identifies those barriers and proposes some effective measures to overcome them.

\section{Methodology :}

This study is mainly based on a review of information collected from secondary sources. The data were collected by the way of consulting various documents such as gazette notifications, annual reports, booklets, articles, books and journals, and newspapers. Some information is also collected from the sources on the internet.

\section{Development of Planning and Women}

A program was undertaken in the first five-year plan for the rehabilitation of women affected during the war of liberation. This is the first time women's development issues have focused on education, health, family planning, and achieving various forms of economic self-reliance. Therefore, with the help of financial resources, a program was undertaken with the help of foreign aid. In 1972, Father of the Nation Bangabandhu Sheikh Mujibur Rahman conferred the title of Birangana on the mothers and sisters who were tortured by the Pakistani army during the war. Bangabandhu's government undertook a massive program to rehabilitate the mothers rescued from the hands of the Pakistani occupying forces. The Bangabandhu government had employed the wives and daughters of the freedom fighters who were martyred in the war of liberation. The then government established the Bangladesh Women's Rehabilitation Board in 1972.

Initiatives were taken in the first five-year plan to involve women in production. The Ministry of Social Welfare introduced scholarship activities. The Ministry of Local Government and Rural Development started mass education activities. This program was later transformed into the women's Cooperative Program with the support of the World Bank. The Department of Women's Affairs undertook an agricultural program for rural women on 33 bighas of land in Savar in 1973.

The program was adopted in a two-year plan (1978-1980) to increase the employment and 
skills of women. A similar program was adopted in the Third Five Year Plan.

The government's vision of gender equality has evolved since the country became independent. In the Fourth Five Year Plan (1990-1995), work has been started to establish gender equality, women's empowerment, and women's rights in the overall development process.

Chapter 10 of the government's Fifth Five Year Plan (1997-2002) emphasizes the environment and sustainable development. One of its objectives is to ensure the active participation of the poor, especially women, in environmental protection activities. Significant policies and strategies have been included in the Sixth Five-Year (2011-2015) Plan to increase women's participation in social, economic, and political life and to remove existing barriers to women's advancement. The plan recognizes the various rights of women and identifies women as successful when adopting a development plan. It follows a two-pronged approach to tackling gender-based inequality: Firstly, gender equality through departmental intervention and secondly paying attention to the elimination of all policies and social prejudices against women.

Most chapters of the government's Seventh Five-Year Plan (2016-2020) focus on gender issues. The first chapter (Section 1.4) deals with the empowerment of women, social inclusion, and social protection through gender equality.

The Gender Policy of the Department of Environment is in line with the National Women's Development Policy 2011 which plans to build a society where men and women have equal opportunities and enjoy all basic rights based on equality. Socially, legally, economically, and politically, the policy has set 20 goals for the empowerment of women in all walks of life. (National Women Development Policy 2011).

The Government of Bangladesh has highlighted gender sensitivity as an important issue in climate change adaptation and has assisted the Ministry of Women and Children Affairs to take initiatives under the Bangladesh Climate Change Trust Fund to integrate gender sensitivity in the design of their projects.

\section{Human Rights of Women and the Constitution}

The Constitution of Bangladesh was drafted in 1972. Under the direction of Bangabandhu Sheikh Mujibur Rahman, the mental and fundamental rights of women have been ensured in the constitution.

In article 27 of the constitution has it that, "all citizens are equal before the law and are entitled to equal protection of the law".

In article28(1) state that, "the State shall not discriminate against any citizen on grounds religion, race, caste, sex and place of birth"

Article 28(2) said, "women shall have equal rights with men in all spheres of the state and public life."

Article 28(3) has it that, no citizen shall, on grounds only of religion, race, caste, sex, or place of birth be subjected to any disability, liability, restriction, or condition about access to any place of public entertainment or resort, or admission to any educational institution."

Article 28(4) says, "Nothing in this article shall prevent the state from making special provision in favor of women or children or for the advancement of any backward section of citizens."

In article 29(1) contains, " there shall be equality of opportunity for all citizens in respect of employment or office in the service of the republic."

Article 29(2) includes that " no citizen shall, on grounds only of religion, race, caste, sex or place of birth, be ineligible for, or discriminated against in respect of, any employment or office in the service of the republic." 
In article 65(3) there are 45 seats reserved for women and under article 9 the representation of women in the development of local government institutions.

In 1978, for the first time, two women were included in Union Parishad (UP) and Gram Sarkar - the lowest tiers of local government - as nominated members under the Local Government Ordinance 1976. The inclusion of women members with the local government's activities was in keeping with the national policy as stressed in the Constitutional Article 10 of part II to ensure the participation of women in nation-building activities.

Article 19 (2): The State shall adopt effective measures to remove social and economic inequality between man and woman and to ensure the equitable distribution of wealth among citizens and of opportunities to attain a uniform level of economic development throughout the Republic.

In 1983, The number of female members was increased to three under the local government (Union Parishads) Ordinance 1983. In 1997, Women were mandated to be directly elected to the UP through three reserved seats in each UP. At present, there are 12,828 elected women members in 4,198 Union Parishads throughout the country. To make the role of women members more effective, some initiatives have been taken through the amendment of the LG Ordinance and various notifications/circulars/ orders of the government.

\section{Current Scenario:}

The government under the leadership of Honorable Prime Minister Sheikh Hasina has undertaken various programs for the establishment of women's rights, their empowerment, and overall development for the implementation of Vision 2021. The Ministry of Women and Children Affairs is implementing various programs to eradicate poverty of women, stop violence against women, stop trafficking in women, ensure full and equal participation of women in the social sphere and ensure protection in all spheres including the workplace. There is a lot of programs taken under the women's safety net like an allowance for the widow and husband abandoned women, lactating mother program in the urban areas, VGD program for the food security of the distressed women, and poverty alleviation loan programs, etc. There are also extensive training programs for women such as agricultural work, sewing, boutiques, handicrafts, grooming, computer operations, and various incomegenerating activities are being implemented. In order to create small and medium entrepreneurs, training is being imparted to increase the skills of women and loans have been provided to them on easy terms. Numerous programs have been included in the National Strategy for Accelerated Poverty Reduction Strategy Paper (NSAPR-II) in this age of globalization aimed at alleviating women's poverty and bringing them into the mainstream macroeconomy. Five strategies have been identified and included in this strategy paper for friendly economic development and the social protection and human resource development of vulnerable groups. Among the five strategies, the most emphasized issue is participatory empowerment in development activities. The Strategy provides for special programs to alleviate the poverty of women by ensuring their empowerment through the expansion of the safety net of poor or extremely poor women. The distribution of allowances for widows and distressed women was started in 1998. It now covers 920,000 women. Under this program, a widow receives an allowance of Tk. 300 per month. They also receive a maternity allowance. Under the maternity allowance, a total of 88,000 poor mothers are given Tk. 350 per month. Also, disability allowances and old age allowances are continued, from which women become beneficiaries. In addition to the poverty alleviation program, $30 \mathrm{~kg}$ of rice or $25 \mathrm{~kg}$ of flour is distributed to 7,50,000 women every month as food security for women's livelihood. The strategy provides for various types of income-generating training to make women self-reliant, especially in agriculture and computer skills. Measures have been taken to provide loan assistance and discounts on interest to small and medium women entrepreneurs on easy terms. Steps have also been taken to remove barriers to production and marketing and to increase financial support. Emphasis has been laid on the development of small scale industries, especially in the home-based textile, handicraft, and weaving industries. 


\section{Women and the Law:}

In Bangladesh, many existing laws have been amended and new laws have been enacted to prevent violence against women and children. Notable among these laws is the Dowry Prevention Act, Prevention of Marriage of Minor Girls, Prevention of Violence against Women and Children Repression Prevention Act, 2000, etc. The Women Violence Prevention Cell and Rehabilitation Centers have been established to provide legal assistance and advice on the prevention of violence against women and children. Above all, the District and Sessions Judge's Court has funds to eliminate legal fees and other expenses.

\section{Organizational and Institutional Transition in Women Development:}

The government formed the Women's Rehabilitation Board in 1972, the Bangladesh Women's Rehabilitation Welfare Foundation in 1974, the National Women's Organization in 1976, and the Ministry of Women's Affairs in 1978 for the advancement of women. The Department of Women's Affairs was formed in 1984 and was upgraded to the Department of Women's Affairs in 1990. In 1994, the Ministry of Women's Affairs has renamed the Ministry of Women and Children's Affairs.

The National Women Organizations implementing women's development programs in 64 districts and 50 Upazilas. Bangladesh Shishu Academy was established in 1976 for the socio-cultural and mental development of children. 44 focal points have been nominated to coordinate the development activities of the Ministry of Women's Affairs and the organization. A 50-member National Council for Women and Child Development (NCWCD) has been formed under the chairmanship of the Prime Minister to implement socioeconomic development, policy formulation, and development programs for women at the national level. An inter-ministerial Committee on Prevention of Violence against Women and Children has been formed to establish rights and prevent violence against women. The Ministry of Women and Child Affairs, the Department of Women's Affairs, and the National Women's Organization have formed the Women and Child Abuse Prevention Cell and the Women Abuse Prevention Committee at the district and Upazila levels. An integrated initiative has been taken to work together for the advancement of women at both public and private levels. The government is actively increasing cooperation with NGOs.

\section{Effective Role of Women and Their Equal Rights in All the National Economic Activity:}

To increase women's participation in decision making in financial institutions.

\subsection{Women Resources:}

There is no substitute for skilled human resources to ensure accelerated national sustainable development and economic growth. Education, healthcare, training, and psycho-cultural development are prerequisites for creating skilled human resources. The government is giving priority to the education sector in its efforts to transform women into skilled human resources. Realizing the importance of primary education has been made compulsory. The stipend program for female students has taken women students forward in the field of education. This program has been very effective in increasing the enrollment of female students in schools and reducing drop out rates. The government is trying to give equal opportunities to women in education, training, science, and technology.

\subsection{Sports and Culture:}

To ensure more participation of women in sports.

To build up a separate sports complex for the women at the grassroots level.

To ensure increased more participation of women in the cultural area.

To arrange government grants for women to make dramas and movies.

\subsection{Education and training:}

To increase education of women, to eliminate discrimination in education rate and opportunities between man and woman, and to follow the Education Policy 2010 aimed at mainstreaming women in the development. 
To continue all-out efforts to eliminate illiteracy of the women and in particular, to give utmost importance to educate and train the female children and women in technical, technological, and scientific pursuits.

To continue with stipends for the female students to ensure participation in the education of the female children.

To take steps to make female education free up to the honors level.

\subsection{Ensuring Human Rights and Fundamental Freedom of Women}

To remove all forms of inequality to women in recognition of the fact that man and woman are all equal in all the areas of human rights and fundamental freedom, such as socio-political, economic, and cultural freedoms.

To take necessary steps to publicize and implement the Convention of the Elimination of All Forms of Discrimination Against Women (CEDAW).

To revise and amend existing law and make necessary legislation to ensure the human rights of women.

Abolishing all discriminatory laws and ensure participation of women legal experts in the commission or committee formed to make legislation and reforms.

To refrain from making any statement or doing anything similar to the interests of local or state level women or taking any initiative based on the misinterpretation of any religion.

Not enacting any discriminatory laws or allowing the promotion of any discriminatory social norms.

Ensuring equal rights at all levels of quality education, employment, technical training, equal assessment, workplace health and safety, social security, and healthcare.

To educate and raise awareness about human rights and women's law.

To arrange for identification of siblings in the name of both parents through all certificates, voter list, form, job application, and passport, etc.

9.5 Co-ordination and Cooperation between GO and NGO programs

Women's organizations are playing an important role in implementing and conducting various activities through coordination and cooperation between the government and NGOs.

\subsection{Poverty}

About $40 \%$ of Bangladesh's population lives below the poverty line and two-thirds of them are women and members of women-led families. Many works done by women have not yet been economically evaluated. In the family, women's labor is spent on household chores and agriculture, which play an important role in alleviating poverty. Women in these fields have not yet been properly assessed. Extremely poor women are being assisted by being included in social security programs.

\subsection{Support Services}

Support services such as child care facilities, workplace day-care centers for children, housing for the elderly, sick, disabled women, healthcare and recreational facilities, expansion and development all target women who are effective participants in economic activities and development processes. 


\subsection{Women and Farming}

The role of agriculture in an agro-based economy is important in achieving food security, employment, and economic growth. Direct and indirect labor and women's participation in agriculture is recognized worldwide. Therefore, women's labor in agriculture needs to be recognized for its contribution to the national economy.

\subsection{Housing and Shelter}

To integrate women's perspectives on planning and housing issues in rural and urban areas.

To emphasize adequate safe housing and housing facilities for single women, women-led families, working women, professionals, trainees, and trained women.

To provide special facilities like hostels, dormitories, old age homes, temporary housing facilities and to reserve the housing of poor, destitute, and working women in urban planning schemes.

\subsection{Special Program for Small Ethnic and Backward Group Women}

To ensure the rights of people belonging to small ethnic and backward groups for their development and advancement.

To take initiative for the development of women belonging to small ethnic groups by retaining their heritage and structure.

To undertake special programs for the development of backward women.

\subsection{Special Program for the Disabled Women}

To ensure rights to recognition and to live with honor and dignity according to the UN disadvantage right convention.

To integrate women with disabilities into mainstream society and ensure active participation in all areas of life, including education.

To emphasis on disability differences in education.

Only consider special types of education in areas where, for obvious reasons, they do not fall into the mainstream.

To undertake appropriate institutional activities for education, treatment, training, and rehabilitation of women with disabilities.

To undertake a program to confine disability and its determination and extending special cooperation to their families for taking care and growth of the disabled women.

To make the structure, facilities, and services accessible to all so that women are not deprived of the rights, facilities, and services available under the National Women's Policy due to disability only.

\subsection{Women and Mass Media}

To take positive initiatives for the appropriate role of women in the media, ensure their access to it, eliminate inequality in participation, and issue projections on women and children issues.

To prevent defamatory, negative, archetype reflection of women and promote propaganda to stop violence against women.

To create equal opportunities in managing different media and formal training for women. To integrate gender perspectives in media policy. 


\subsection{Women distressed in special circumstances}

To take initiative if a woman falls ill in a special situation, consider her needs, and take measures to help her.

\subsection{Women Development Training Institute}

In addition to strengthening the existing Women's Development Training Institute, training centers should be set up in divisions, districts, and Upazilas. These centers will provide technical and vocational training to women as well as raise awareness on issues related to their rights and education.

\section{Making Gender Responsive Budget and Gender Disaggregated Database}

To continue gender-responsive budgeting to ensure women's advancement.

To continue the use of gender-responsive budgeting (GRB) in the case of state budgets for implementation within the framework of appropriate gender-responsive budgets and midterm budgets.

In 2016-17, the number of working women in Bangladesh increased to 18.6 million from 16.2 million in 2010. According to the Global Gender Gap Report, in 2017, Bangladesh was ranked 47th out of 144 countries where India, Sri Lanka, Nepal, Bhutan, and Pakistan ranked 108, 109, 111, 124, and 143 respectively.

Over the past decade, Bangladesh has been a role model in women's empowerment and the country is experiencing a commendable change in society due to its efforts in this regard.

In this regard, the concept of women's empowerment and efforts has helped the country to make uninterrupted progress in the field of gender equality, which helped Bangladesh to achieve the first position in gender equality (among South Asian countries) for the second year in a row in the Gender Gap Index 2017.

\section{Implementation Mechanism}

The processes for implementing the National Women's Development Policy are as follows: The main responsibility of the government is to implement women's development policy and work plan. This responsibility can be discharged on a perfect basis by building a wellorganized and broad-based institutional system. Attempts will be made to include aspects of women's development in all GO and NGO activities. The following issues will be considered with these views:

\subsection{National Level}

(a) Institutional Framework for Development of Women: National structures such as the Ministry of Women and Children Affairs, the Department of Women's Affairs, the National Women's Organization and the administrative structure of the Bangladesh Shishu Academy will be further strengthened. The manpower and resources of these agencies will be ensured. The administrative structure of these divisions will be gradually expanded to all divisions, district, Upazila and union levels. The power and authority of this organization will be enhanced for the implementation and monitoring of all programs for the development of women.

(b) National Women and Child Development Council (NCWCD): A 50-member National Council for the Development of Women and Children has been formed under the chairmanship of the Prime Minister.

(c) Parliamentary Committee: After reviewing the Women's Development Program, the Parliamentary Standing Committee on Women's Development constituted by the Parliament of Bangladesh will advise the Government to take specific initiatives for the advancement of women. 
(d) A focal point in Women Development: Various focal points of the Ministry / Division / Agency will take up programs, create projects and implement them in the light of the National Women's Policy. At least Joint Secretaries / Joint Chiefs will be nominated as focal points in those agencies for proper implementation of women development programs in various Ministries / Departments / Agencies. These issues will be reviewed and discussed at the monthly ADP meetings and monthly coordination meetings of the Ministry / Division / Agency for regulatory monitoring of the Women's Development Program.

A Women's Development Implementation and Evaluation Committee will be formed which will consist of a representative of the focal Point Ministry and the Minister for Women's Development and Child Development. This committee will review, coordinate and evaluate programs related to women's development. The committee will identify the problems of its concerned ministries and agencies and make recommendations to expedite future programs.

(e) District and Upazilla Levels: The program of the district level administration, Zilla Parishad, Municipality, Local Government, Office of the concerned ministry will be coordinate and advancement of women development program reviewed for progress and empowerment of the women. The District Women's Affairs Officer, Upazila Women's Affairs Officer in coordination with other concerned officers will be responsible for implementing all the programs taken for the development of women.

(f) Grassroots Level: At the grassroots level i.e. in villages and unions, women will be organized as self-help groups. To strengthen these groups, they will be transformed into registered organizations under various government agencies. Tapping resources from the Government Organization and Non-Government Organization sources, banks, other financial institutions, an intimate relationship of these organizations with Union Parishad, Upazilla Parishad, Zilla Parishad, Municipality and City Corporation will be established and their activity co-ordinate. Above all, the inclusion of local grassroots perspectives of all grassroots organizations will be encouraged and supported.

\section{Women Empowerment in Different Sectors of Bangladesh}

The twenty-first century is ushering in a new era of hope and aspiration for women. With pride and hope, the women of Bangladesh can look forward to some outstanding and significant moments in the overall development that has taken place over the past two decades. Amarta Sen famous economist and Nobel laureate have also praised Bangladesh's performance in women empowerment (An Uncertain Glory: India and its Contradiction, 2013). Empowerment of women in various fields of Bangladesh has been highlighted here as a contribution to the National Women's Development Policy.

\subsection{Women and Education}

Gender priority has been achieved in primary education. Between 1990 and 2008, the number of primary school enrollments increased 1.4 times. The enrollment of female students in secondary education increased significantly as girls $(52 \%$ for girls) have surpassed boys (48\% for boys) in 2000. Special importance has been given to the education of girls. The provision of free stipends for girls in primary and secondary education and waiver of tuition fees has increased the enrollment of girls. To increase the participation of women in technical and vocational education, three women's polytechnic institutes have been established at the three divisional headquarters. International Women's University, Chittagong and Central Women's University, Dhaka have been established to provide higher education and opportunities to women(GoB, Ministry of Women and Children Affairs, 2011).

\subsection{Women and Health}

Significant gains have been made in women's health. Initiatives have been taken to provide primary health care services to rural poor women through community clinics. As a result of the reduction in maternal mortality rate, special attention is being paid to facilitate 
maternal health care. Ten women-friendly model district hospitals and three Upazila health complexes have been set up for the treatment of women and children.

\subsection{Employment of Women in Different Sectors}

There is a tendency to increase women's participation in the labor force. Women's participation in the labor force has increased significantly from $23.9 \%$ in $1999-2000$ to $29.2 \%$ in 2005-2006. The role of rural women as agricultural workers has gradually expanded from $25 \%$ to $34 \%$ between 2002-2003 and 2005-2006. This indicates an increase in the female workforce in the agricultural sector from $7.6 \%$ in $2002-2003$ to $10.11 \%$ in 2005-06. A micro-level survey conducted in 2008 revealed that $88 \%$ of women are engaged in agricultural work(GoB, Ministry of Women and Children Affairs, 2011). 40 lacs women are employed in Garment sectors (GoB, Ministry of Labor and Manpower, 2010).

\subsection{Social Empowerment}

The number of women employed in various professions such as civil service and administration, judiciary, armed forces, navy and the air force has increased. Recently, female police officers have also been recruited. Women are enlisted in the armed forces in UN peacekeeping missions and the All Women Formed Police Unit (FPU) has been sent to Haiti. Evidence that women can take part in conflict resolution, crisis management and post-war rehabilitation under the Security Council Resolution 1325. Maternity leave for all women in government service has been extended by six months and the number of day-care centers has also increased.

\subsection{Legal Empowerment}

Bangladesh has several special laws to prohibit certain types of violence against women, including the 1960 Penal Code; Anti-Dowry Act 1980; Prevention of Repression Against Women and Children Act 2000 (revised in 2003), Acid Crime Control Act, etc. There are also a few other notable laws imposed by the government to ensure both legal protection and women's empowerment. They are as follows:

a. The Citizenship (Amendment) Act, 2009. It gives a Bangladeshi woman the right to send citizenship to her children.

b. Domestic Violence (Prevention and Protection) Act 2010

c. The Representation of People's (Amendment) Ordinance, 2008 (One woman will be elected as one of the two vice-chairmen in each Upazila)

d. National Human Rights Commission Act, 2009 (At least one female member should be included in the Human Rights Commission)

e. Right to Information Act, 2009 (Having women as information commissioners)

f. The gazette identification of the mother in 2000 confirmed that the mother's name along with the father's name must be entered in all official documents as a form of school admission and passport etc.

\subsection{Political Empowerment}

The advancement of women in politics in Bangladesh is significant because women hold top positions in political leadership. At the highest decision-making stage, a significant number of women ministers are present in the cabinet, including the Hon'ble Prime Minister of the state. The political empowerment of women in local government has also gained momentum. The local Government (Union Parishad) amendment act 1997 ensures direct election to the reserved seats for women. This is a milestone in ensuring equal access to women in the political power structure. Subsequently, at the Upazila level, the position of vice chairman for directly elected women has been identified. In addition to the Hon'ble Prime Minister, the current Leader of the Opposition, Member of Parliament, Deputy Leader, Speaker, Whip, Chairman and members of various Standing Committees in Parliament and notable members of the Cabinet are women and they hold strong political positions. In the tenth national election, 48 women were directly elected members of parliament. It added to the reserves, making up $28 \%$ of the total seats. The People's (Amendment) Ordinance, 2008 represents that at least 33\% of all committee positions should be reserved for women in political parties. 


\subsection{Economic Empowerment of Women}

The essentials for women's economic empowerment are;

To provide full and equal opportunities to women in health, education, training, lifelong learning (continuing education), technical education, income-generating training, information and technology, etc.

To provide women with the right to inherit and market management through middle income earning loans etc.

\section{Problems of Women Empowerment in Bangladesh}

In the field of women's advancement and rights, the government is committed and has taken various initiatives to reduce the gap between men and women. However, on the way to achieving the desired goal of gender equality and gender mainstream, there are still some challenges. These include:

a. Women's economic participation is low. Poor women have lower earning potential and their wages are lower than male wages. Women-run families usually face discrimination.

b. Violence against women is widespread. Physical and sexual assaults, including acid throwing, are common. Also, there are reports of trafficking. Poverty, dowry, child marriage, prejudice, social attitudes, etc. are the main causes of violence against women.

c. Marriage at a young age stops women from studying and as a result of early delivery. They have fewer opportunities for employment and decision making.

d. With outbreaks of droughts, floods, cyclones and other natural disasters, women are affected differently than men which indicates the need to increase gender sensitivity in coping methods and strategies.

e. The main problem of gender administration is the implementation of existing laws, rules and regulations as well as state policy. Also, some laws, regulations, policies and institutional processes need to be reformed to make the administration gendersensitive.

f. Moreover, the traditional society and its limited social attitudes, religious barriers, purdah system, etc., have remained a constant flaw in women's empowerment in Bangladesh.

\section{Concluding Remarks}

Women of Bangladesh are the driving force for the development of Bangladesh. As women make up half of the total population of Bangladesh, they can contribute a lot to sustain Bangladesh's fragile economy. Therefore, women in Bangladesh need to be seen as potential contributors to all development processes. Development of the country is impossible without the empowerment of women. The empowerment of women can lead to rapid growth in the development of the country. According to the World Bank, Bangladesh will become a middle-income country by 2021 . Bangladesh is one of the 11 potential countries that will surpass the countries of the European Union within 2030 (National Intelligence Council of USA). Therefore, for the real development of our country, active cooperation and participation of both men and women are required. In this case, it is important to implement the national women's development policy. The implementation of this policy can ensure the empowerment and overall development of women in Bangladesh. Therefore, GOs, NGOs, international organizations, civil society and social workers must play a key role in implementing the National Women's Development Policy.

\section{References:}

[1]. Asadullah, Mohammad Niaz, NazmulChaudhury and Amit Dar. (2006). Conditional Cash Transfers and Educational Gender Gaps: Insights from Bangladeshi Households. Background Paper for the Bangladesh Gender Assessment. Washington DC: The World Bank (April 2006)

[2]. Bangladesh Bureau of Statistics (BBS). (2011). Bangladesh Population Census- 2011.Dhaka: Ministry of Planning.

[3]. Choudhury K. K., M. A. Hanifi, S. Rasheed, A. Bhuiya. (2000). "Gender inequality and severe malnutrition among children in a remote rural area of Bangladesh." Journal of Health, 
Population and Nutrition 18(3):123-30.

[4]. Government of Bangladesh (GoB). (2005). Bangladesh - Unlocking the Potential: National Strategy for Accelerated Poverty Reduction. Dhaka, Bangladesh: General Economics Division (GED), Planning Commission.

[5]. Government of the People's Republic of Bangladesh. (2008). TPP on Promotion of Gender Equalities and Women Empowerment (2006-10). Dhaka; Ministry of Women and Children Affairs.

[6]. Government of the People's Republic of Bangladesh. (2010). Labor Force Survey-2010. Dhaka: Ministry of Labor and Manpower.

[7]. Government of the People's Republic of Bangladesh. (2011). National Women Development Policy, 2011. Dhaka; Ministry of Women and Children Affairs.

[8]. Government of the People's Republic of Bangladesh. (2011).Sixth Five Year Plan 2011-2015. Dhaka; Ministry of Planning.

[9]. Government of the People's Republic of Bangladesh. (2011).The Constitutions of the People's Republic of Bangladesh, 2011. Dhaka; Ministry of Law and Parliamentary Affairs.

[10]. Government of the People's Republic of Bangladesh. (2013). Bangladesh Economic Review2013. Dhaka; Ministry of Planning.

[11]. Hassan, M. (2006). Access to Formal and Informal Justice System and Legal Empowerment Strategies in Bangladesh. Background Paper for the Bangladesh Gender Assessment Dhaka: The World Bank (mimeo)

[12]. Hossain, S-Z. (2017). Bangladesh has made progress in leaps and bounds in closing the gender gap in the last 10 years, according to the World Economic Forum's Global Gender Gap Report 2017.

[13]. Khan, E-P.(2017). "The Prevention of Women \& Children Repression Act 2000: A Study of Implementation Process from 2003 to 2013." IOSR Journal Of Humanities And Social Science (IOSR-JHSS) 22.7 (2017): 34-42.

[14]. Koenig, Michael A, S Ahmed, MB Hossain and ABMKA Mozumder. (2003). "Women's status and domestic violence in rural Bangladesh: Individual and community-level effects" Demography; 40, 2; pg. 269

[15]. Koenig, Michael A., Saifuddin Ahmed, Mian Bazle Hossain, and A.B.M. Khorshed AlamMozumder. (2003). "Women's Status and Domestic Violence in Rural Bangladesh: Individual- and Community-Level Effects.” Demography 40(2): 269-288.

[16]. Mahmud, Simeen. (2006). Economic participation of women in Bangladesh. Background Paper for the Bangladesh Gender Assessment. Dhaka: The World Bank.

[17]. Mumtaz, K. (2005). Women's Representation, Effectiveness and Leadership in South Asia. Fifth South Asian Regional Ministerial Conference, Islamabad, Pakistan, May 2005. link: http:///www.unifem.org.in/pdf/Women_representation.pdf

[18]. Rabbani, G.(2004). 'Women Empowerment in Bangladesh: Problems \& Prospects' in the Journal of Social Development, Vol-16, No-1 December 2004.

[19]. Schuler, Sidney Ruth, Lisa M. Bates, Joanna Maseljo and Farzana Islam. ( 2006). Women's rights and gender-based violence and recourse-seeking in rural Bangladesh. Report prepared for the Bangladesh Human Rights Advocacy Program, Center for Civil Society and Governance, Academy for Educational Development. Dhaka: March 2006.

[20]. World Bank. (2004). Bangladesh - Development policy review: impressive achievements but continuing challenges. Washington, DC: World Bank.

[21]. World Bank. (2005a). Bangladesh - Attaining the Millennium Development Goals in Bangladesh Washington, DC: World Bank.

[22]. World Bank. (2005b). Maintaining Momentum Toward the MDGs: An Impact Evaluation of Interventions to Improve Maternal and Child Health and Nutrition Outcomes in Bangladesh. Washington, DC: World Bank.

[23]. World Bank. (2006a). Survey of Gender Norms. Dhaka

[24]. World Bank. (2006b). Economics and governance of non-governmental organizations in Bangladesh. Washington, DC: World Bank.

[25]. World Health Organization (WHO). (2005). WHO Multi-country Study on Women's Health and Domestic Violence against Women Geneva: WHO

[26]. World Bank. (2008). 'Whispers to Voices: Gender and Social Transformation in Bangladesh,' Bangladesh Development Series Paper No.22, Dhaka.

[27]. Zuckerman, E. (2003). Gender Analysis of" Bangladesh: A National Strategy for Economic Growth, Poverty Reduction and Social Development." (Interim-PRSP). Gender Action, New York. 